\title{
Study on vector mosquito of zoonotic Brugia malayi in Musi Rawas, South Sumatera, Indonesia
}

\author{
Budi Mulyaningsih ${ }^{1}$, Sitti Rahmah Umniyati ${ }^{1}$, Suwarno Hadisusanto ${ }^{2}$ and Erwin Edyansyah ${ }^{3}$
}

1. Department of Parsitology, Faculty of Medicine Public Health and Nursing, Universitas Gadjah Mada, Yogyakarta, Indonesia; 2. Department of Tropical Biology, Faculty of Biology, Universitas Gadjah Mada, Yogyakarta, Indonesia; 3. Postgraduate Program of Medicine, Faculty of Medicine Public Health and Nursing, Universitas Gadjah Mada, Yogyakarta, Indonesia.

Corresponding author: Budi Mulyaningsih, e-mail: budi.mulyaningsih@ugm.ac.id

Co-authors: SRU: sitti-rahmah@ugm.ac.id, SH: suwarnohs@ugm.ac.id, EE: erwin.edyansyah@mail.ugm.ac.id Received: 31-05-2019, Accepted: 27-09-2019, Published online: 07-11-2019

doi: www.doi.org/10.14202/vetworld.2019.1729-1734 How to cite this article: Mulyaningsih B, UmniyatiSR, HadisusantoS, Edyansyah E (2019) Study on vector mosquito of zoonotic Brugia malayi in Musi Rawas, South Sumatera, Indonesia, Veterinary World, 12(11): 1729-1734.

\begin{abstract}
Background and Aim: Studies to determine abundance, distribution, species composition, and mosquito interactions are very important in understanding the risk of disease transmission to implement appropriate mosquito management in endemic areas. Lymphatic filarial worms are one of the parasites that are contracted and/or transmitted by mosquitoes when sucking the blood of infected humans or animals and then biting others. This research was conducted to study the abundance, species composition, mosquito biting cycles, density and periodicity of mosquitoes caught in Lubuk Pauh Village, Bulang Tengah Suku Ulu, Musi Rawas, South Sumatera, Indonesia, which is an endemic area of zoonotic Brugia malayi.

Materials and Methods: The mosquito collection was done in July 2018 using the human landing collection method for $11 \mathrm{~h}$ from $18.00 \mathrm{pm}$ to $5.00 \mathrm{am}$ Western Indonesian Time. The catching of mosquitoes was done both indoors and outdoors, and mosquitoes were identified under a dissecting microscope using an identification key to confirm their species. Detection of $B$. malayi larvae in mosquitoes was confirmed by dissection and polymerase chain reaction methods.

Results: The caught mosquitoes consisted of four species: Armigeres subalbatus, Culex quinquefasciatus, Culex vishnui, and Mansonia uniformis. Based on the Shannon-Wiener index, Lubuk Pauh Village has low mosquito species diversity (0.210). Ar. subalbatus was the dominant mosquito in Lubuk Pauh Village with dominance number 95.08, and it had the most frequent activity in each of periods of indoor and outdoor collection, with the highest density (man-hour density) at 18.00-19.00 (51.750). B. malayi infective stage larvae were not found in all mosquito species caught.
\end{abstract}

Conclusion: Existence of Ar. subalbatus, Cx. quinquefasciatus, and Ma. uniformis in Lubuk Pauh Village which is an endemic area of $B$. malayi shows that the area is at risk of lymphatic filariasis transmission.

Keywords: Armigeres subalbatus, Brugia malayi, lymphatic filariasis, Musi Rawas, South Sumatera.

\section{Introduction}

Lymphatic filariasis, commonly called elephantiasis, is one of the neglected tropical diseases. At present, 856 million people in 52 countries are living in areas that require preventive chemotherapy to stop the spread of this infection [1]. Epidemiologically, Indonesia is in an area that is at high risk of contracting filariasis [2]. In South Sumatera Province, lymphatic filariasis is present in almost all districts. Musi Rawas Regency is one of the endemic areas of filariasis and in 2014-2016, 29 chronic sufferers were reported in three villages [3]. Lymphatic filarial worms are one of the parasites that are contracted and/or transmitted by mosquitoes when sucking the blood of infected humans or

Copyright: Mulyaningsih, et al. Open Access. This article is distributed under the terms of the Creative Commons Attribution 4.0 International License (http://creativecommons.org/licenses/ by/4.0/), which permits unrestricted use, distribution, and reproduction in any medium, provided you give appropriate credit to the original author(s) and the source, provide a link to the Creative Commons license, and indicate if changes were made. The Creative Commons Public Domain Dedication waiver (http:// creativecommons.org/publicdomain/zero/1.0/) applies to the data made available in this article, unless otherwise stated. animals and then biting others. The ability of vector mosquitoes to swallow filarial worms and to support their development after being in their bodies is an important determinant of transmission of filariasis. The amount of microfilaria that is sucked and that develop into infective stage larvae (L3) is not constant and depends on many factors that influence their maturity. Lymphatic filariasis is transmitted by many species of mosquitoes in four principal generaAnopheles, Culex, Aedes and Mansonia, the distribution, ecology, biology and transmission potential of which vary greatly. As transmission efficiency differs considerably by vector species, it is important to understand the entomological aspects of transmission of lymphatic filariasis. Mansonia spp is the main vector of zoonosis malayan filariasis [4]. Lymphatic filariasis is caused by three filarial worm species, namely, Wuchereria bancrofti, Brugia malayi, and Brugia timori. All of these species are found in Indonesia, but more than $70 \%$ of filariasis cases in Indonesia are caused by B. malayi. Malayan filariasis is one of the zoonotic diseases that can be transmitted from animals to humans. This disease has reservoir hosts and 
mosquito vectors. Humans are considered the main definitive host of filariasis, but there are several types of animals that can act as sources of filariasis transmission. Of all the filarial worm species that infect humans in Indonesia, only B. malayi nocturnal subperiodic type, and non-periodic type are found in animals, namely, monkey (Macaca fascicularis), lutong or black monkey (Presbytis cristatus), and cats (Felis catus). The presence of animals that become filariasis reservoir host will be one of the problems in efforts to eliminate filariasis in Indonesia [5]. Research in Narathiwat Province, Southern Thailand, from the results of 2515 cats, 401 cats were positive for microfilaria B. malayi [6] and in East Kalimantan from the results of microfilariae examination in 645 cats found 14 cats positive for microfilaria B. malayi [7].

At present, there are 23 species of mosquitoes from the genera Anopheles, Culex, Mansonia, and Armigeres that can act as filariasis vectors in Indonesia [2]. The study aimed to determine density, abundance, distribution, and species composition, and host and mosquito interactions are very important in understanding the risk of disease transmission to apply appropriate mosquito management. Thus, understanding the factors that modulate vectors and host distribution, density, and abundance, as well as vector mosquito biting behavior, are important steps in characterizing the risk of transmission and consequences of vector-borne diseases.

\section{Materials and Methods \\ Ethical approval}

This research was conducted in July 2018 and has been approved by the Medical and Health Research Ethics Commission of the Faculty of Medicine, Public Health, and Nursing Universitas Gadjah Mada, with numbers KE/FK/0389/EC/2018. The design of this study was cross-sectional with a spot survey design.

\section{Study sites}

The study was conducted at four hamlets (Hamlet I, II, III, and IV) in Lubuk Pauh Village, Bulang Tengah Suku (BTS) Ulu Sub-district, Musi Rawas District, South Sumatera Province, Indonesia. Musi Rawas district is one of the endemic areas of Malayan filariasis in South Sumatera.

\section{Mosquito sampling}

A mosquito sampling was done using human landing collection (HLC) in two houses in every hamlet in Lubuk Pauh Village for $11 \mathrm{~h}$ from $18.00 \mathrm{pm}$ to 05.00 am Western Indonesian Time (WIT). Catching mosquitoes were done both indoors and outdoors by a team of four trained volunteers per house, with two volunteers sitting in the house, and two volunteers sitting outside the house. To determine mosquito biting cycles, HLC was conducted hourly for $40 \mathrm{~min}$ for the two groups (indoors and outdoors), each with two persons, for two consecutive nights. Mosquitoes caught were put in paper cups covered with net and then sorted and identified morphologically using the identification keys with a dissecting microscope.

\section{Detection of microfilaria/larva B. malayi in mosquitoes}

Each species of mosquito caught, which was considered to be able to act as a vector of $B$. malayi was examined by dissection and molecularly with polymerase chain reaction (PCR) methods to determine whether there were microfilariae or $B$. malayi larvae by pooling method (10-25 mosquitoes). In this method, a group of mosquitoes was put on the object-glass, some drops of physiological saline solution were added, and the mosquitoes were pressed with another object-glass, until the body of the mosquitoes separated into several parts. Mosquitoes were then moved into a Petri dish which has been filled with physiological saline solution to soak the body parts of the mosquitoes. The immersion of the mosquitoes was left for 5-10 min, and the Petri dish was observed under the dissecting microscope.

The procedure for the detection of microfilariae or larvae of $B$. malayi in mosquitoes by pooling method of 10-25 mosquitoes using PCR method was carried out through several activities as following: DNA isolation, running PCR, and electrophoresis. Female mosquitoes were collected based on species. Each pool then homogenized with a pestle in a tube microcentrifuge containing $180 \mu \mathrm{l}$ phosphate buffer saline ( $\mathrm{pH}$ 7.2). DNA was further extracted from each tube using Genomic DNA mini Kit GeneaidTM Cat No. GB100. Lot No.JM02202, according to company protocol. Amplification of PCR is carried out with thermocycler using HhaI forward primers (5 'GCGCATAAATTCATCAGC-3') and reverse HhaII (5'GCGCAAAACTTAATTACAAAAGC-3'). The PCR mixtures contained $15 \mu \mathrm{l}$ of Mix PCR (GoTaq ${ }^{\circledR}$ Green Master Mix. $2 \times$ ), $11 \mu$ of ddH2O (nuclease-free water lot. 0000123190 Promega), $2 \mu 1$ of $\mathrm{R}$ and $\mathrm{F}$ primers $(20 \mu \mathrm{M})$, and $2 \mu \mathrm{l}$ of the DNA template in a total volume of $30 \mu \mathrm{l}$. The temperature was programmed under the following conditions: One cycle of initial denaturation at $94^{\circ} \mathrm{C}$ for $5 \mathrm{~min}$, followed by 40 cycles of $94^{\circ} \mathrm{C}$ for $1 \mathrm{~min}$ (denaturation), $56^{\circ} \mathrm{C}$ for $1 \mathrm{~min}$ (annealing), and $72^{\circ} \mathrm{C}$ for $1 \mathrm{~min}$ (extension); and a final extension step at $72^{\circ} \mathrm{C}$ for $10 \mathrm{~min}$. Following the PCR $20 \mu \mathrm{l}$ of each PCR product was electrophoresed on a $\%$ agarose gel, stained with ethidium bromide, and observed under UV. Mosquito samples were found positive for the filarial parasite (B. malayi), if exhibited amplification of $322 \mathrm{bp}$ DNA fragment [8].

\section{Statistical analysis}

The diversity of mosquito species was analyzed by Shannon-Wiener diversity index [9]. Other entomological indexes were calculated, such as relative abundance, species frequency, the dominant number, periodicity of mosquito, and species mosquito density [10]. 


\section{Results}

Species diversity-dominance, relative abundance frequency of mosquitoes

During the collection period with the HLC for $11 \mathrm{~h}$ (18.00-05.00 WIT) in Lubuk Pauh, at coordinates S $3^{\circ}$ 13 ' 17.3"; as many as, 630 mosquitoes were obtained consisting of four mosquito species. Based on the Shannon-Wiener index, Lubuk Pauh Village has low mosquito species diversity (0.210). Diversity of species was expressed by $\mathrm{H}$ index $(\mathrm{H} 1)$, which included the low category if the number is $<1$, medium category if the number is more than 1 , and $<3$ and high category if the number is more than 3 [11]. Species diversity of mosquitoes caught in Lubuk Pauh Village, as shown in Table-1.

Based on the composition of the species of mosquito caught, Armigeres subalbatus was the dominant mosquito species (599). This study also showed that the number of mosquitoes collected outdoors (411) was higher than those caught indoors (219). Mosquitoes collection were done for two consecutive nights and there were 22 collecting hours. The relative

Table-1: Species diversity of mosquitoes caught in Lubuk Pauh village by human landing collection method.

\begin{tabular}{lccc}
\hline Mosquito species & \multicolumn{2}{c}{$\begin{array}{c}\text { Human landing } \\
\text { collection }\end{array}$} & Total \\
\cline { 2 - 3 } & Indoors & Outdoors & \\
\hline Armigeres subalbatus & 206 & 393 & 599 \\
Culex quinquefasciatus & 11 & 18 & 29 \\
Culex vishnui & 1 & - & 1 \\
Mansonia uniformis & 1 & - & 1 \\
Number of mosquitoes & 219 & 411 & 630 \\
\hline
\end{tabular}

abundance, species frequency, and dominant species of mosquito species caught in Lubuk Pauh Village with HLC method are shown in Table-2.

\section{Density and periodicity of Ar. subalbatus}

Ar. subalbatus was the dominant mosquito in Lubuk Pauh Village, and it had the most frequent activity in each of the periods, both indoor and outdoor collection. Density (man-hour density) of Ar. subalbatus is presented in Table-3. Table-3 shows that Ar. subalbatus is active all night both indoors and outdoors, with the highest density (man-hour density) at 18.00-19.00 WIT, which is equal to 51.750.

\section{Behavior of Ar. subalbatus in Lubuk Pauh village}

All mosquito species have their own distribution, behavior pattern, and characteristics of its habitat, which are different from others. The daily behavior pattern of mosquito activities will occur at day or night time depending on the species. From the results of this study, it can be seen that the Ar. subalbatus is active all night from 18:00 to 05:00 WIT. The highest activity of Ar. subalbatus that was collected on human bait was between 18:00 and 19:00 WIT both indoors and outdoors (Figure-1).

\section{B. malayi larvae detection in mosquitoes}

Dissection of Ar. subalbatus, Culex quinquefasciatus, Culex vishnui, and Mansonia uniformis that were caught in Lubuk Pauh did not find filariasis larvae. Similarly, the molecular examination using the PCR methods also showed negative results. This result means that filarial larvae were not found in all mosquito species caught.

Table-2: The relative abundance, species frequency, and dominance numbers of mosquitoes caught in Lubuk Pauh Village with the human landing collection method.

\begin{tabular}{lcccc}
\hline Mosquito species & Number of mosquitoes & \multicolumn{2}{c}{ Human landing collection } \\
\cline { 3 - 5 } & & $\begin{array}{c}\text { Relative abundance Species frequency Dominance numbers } \\
\mathbf{( \% )}\end{array}$ & \\
\hline Armigeres subalbatus & 599 & 95.08 & 1.00 & 95.08 \\
Culex quinquefasciatus & 29 & 4.60 & 0.86 & 3.96 \\
Culex vishnui & 1 & 0.16 & 0.04 & 0.006 \\
Mansonia uniformis & 1 & 0.16 & 0.04 & 0.006 \\
\hline
\end{tabular}

Species frequency without \%, Dominance numbers without \%

Table-3: The MHD of Ar. subalbatus from Lubuk Pauh village, July 2018.

\begin{tabular}{lccc}
\hline Mosquito collecting time & \multicolumn{2}{c}{ Armigeres subalbatus density (MHD) } & Total of MHD \\
\cline { 2 - 3 } & Indoors & Outdoors & \\
\hline $18.00-19.00$ & 17.250 & 34.500 & 51.750 \\
$19.00-20.00$ & 7.500 & 16.500 & 24.000 \\
$20.00-21.00$ & 5.625 & 11.625 & 17.250 \\
$21.00-22.00$ & 7.125 & 9.000 & 16.125 \\
$22.00-23.00$ & 7.500 & 9.000 & 16.500 \\
$23.00-24.00$ & 7.125 & 10.500 & 17.625 \\
$24.00-01.00$ & 4.875 & 13.875 & 18.750 \\
$01.00-02.00$ & 5.625 & 11.250 & 16.875 \\
$02.00-03.00$ & 6.000 & 7.875 & 13.875 \\
$03.00-04.00$ & 5.625 & 10.875 & 16.500 \\
$04.00-05.00$ & 5.250 & 9.000 & 14.250 \\
\hline
\end{tabular}

MHD=Man-hour density 


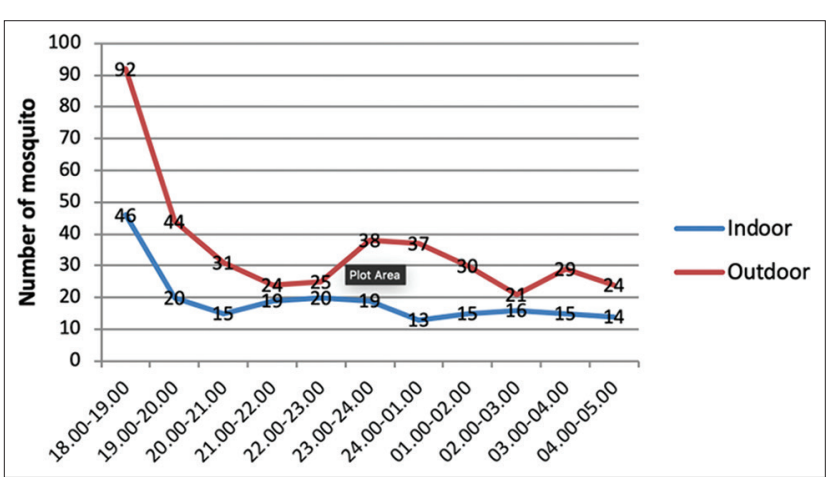

Figure-1: Periodicity of Armigeres subalbatus from Lubuk Pauh village.

\section{Discussion}

Lubuk Pauh Village is one of the endemic areas of Malayan filariasis in South Sumatera, Indonesia (S 3 $\left.{ }^{\circ} 13^{\prime} 17.3^{\prime \prime}\right)$. This village is still categorized as an underdeveloped village, located on the banks of the Musi River with a typology of rubber plantation land so that the majority of the population works as rubber farmers. In this area, four species of mosquitoes were found, which included Ar. subalbatus, Cx. quinquefasciatus, Cx. Vishnui, and Ma. uniformis, with low mosquito species diversity (Shannon-Wiener index $0.210)$. This finding is probably due to the landing collection of the mosquitoes that were only done twice in July 2018 because it was a preliminary study to find out the picture of mosquitoes found in endemic areas of Malayan filariasis. At that time, in the area, it was in the dry season and experiencing drought. Mosquitoes are cosmopolite insects, which are widespread in the tropic and sub-tropic regions. Seasonally, the changing of the environment also affects their activity and impacts on their diversity, distribution, and density. Research has shown that mosquitoes can be competent vectors, efficient distributors, and reinforcing agents for various parasites in animal and human populations $[11,12]$.

The most dominant mosquito caught was Ar. subalbatus, which is commonly found close to human dwellings, especially in suburban areas with poor sanitation that contains polluted water such as septic tanks. The density (man-hour density) of Ar. subalbatus outdoors was higher than indoors. This was allegedly due to the character of Ar. subalbatus that is more exophilic. Ar. subalbatus is closely linked with artificial habitats and also breeds in tree holes and has been known to be a vector of Japanese encephalitis virus, a vector of filarial worm $W$. bancrofti in India and the dog heartworm Dirofilaria immitis in Peninsular Malaysia [13-15]. This mosquito species is also the vector for the zoonotic Brugia pahangi infection in Malaysia, and therefore should now be categorized as a medically important mosquito species. Its central role in the transmission of zoonotic B. pahangi must be considered important in future studies on filarial infections [16].
In this study, the dominance numbers of $C x$. quinquefasciatus, $C x$. vishnui, and Ma. uniformis were very low. $C x$. quinquefasciatus is a vector of the $W$. bancrofti urban type, and in Pekalongan (Central Java), Indonesia, it has been confirmed that $C x$. quinquefasciatus is a $W$. bancrofti vector. Shriram et al. reported that Cx. quinquefasciatus is a $W$. bancrofti diurnal subperiodic type vector in Nicobarase, Nicobar Island, and India [17]. Iris et al. also reported that $C x$. quinquefasciatus is a $W$. bancrofti vector in Tanzania [18]. In the research conducted by Safitri on $C x$. quinquefasciatus from Barito Kuala District, Kalimantan, B. malayi larvae were found [19]. This finding can happen because the environment in these places is suitable for $C x$. quinquefasciatus and B. malayi worms. Research conducted by Yahya et al. shows that $C x$. quinquefasciatus has more potential to be a $B$. malayi vector than Ar. subalatus [20].

Very few Ma. uniformis were caught in Lubuk Pauh Village, BTS Ulu Sub-district, Musi Rawas District, South Sumatera Province, Indonesia. The previous study showed that Ma. uniformis in Sedang, Suak Tapeh, Banyuasin, South Sumatera, and also in Karanganyar Village, Banyuasin, South Sumatera were the dominant mosquito [21,22]. The Indonesian Ministry of Health reported that in South Sumatera, filariasis is caused by $B$. malayi and the vector is Ma. uniformis [23]. The character of $M a$. uniformis breeding places can affect the incidence of lymphatic filariasis. The research of Sapada et al. in Banyuasin (South Sumatera) and Zen in East Lampung showed that environmental conditions with many aquatic plants such as swamps and ponds can be ideal breeding places for Mansonia spp. and are associated with the incidence of lymphatic filariasis [24,25]. Ma. uniformis is the main vectors of zoonotic $B$. malayi nocturnal subperiodic type in South Sumatera Province, Indonesia, and in Southeast Asia, however, in Africa, Ma. uniformis and Mansonia africana are the main vectors of $W$. bancrofti $[5,23,26]$. Studies of bloodsucking mosquito activity can be used to take preventive measures to avoid filariasis vector mosquito bites. Many factors can influence potential vectors to be positive for microfilaria including the amount of microfilariae that are sucked is sufficient or not to develop in the body of a mosquito. The requirements for mosquitoes to become vectors include the age of mosquitoes, contact between humans and animals (hosts) with mosquitoes, the frequency of bloodsucking, and the susceptibility of mosquitoes to parasites [10]. The estimated capacity to be a vector is influenced by environmental, behavioral, biochemical, and cellular factors that influence the relationship between vectors, pathogens that will be transmitted by vectors, and hosts where the pathogen will be transmitted. Behavior and environmental factors have a role in distinguishing the 
mosquitoes' capacity as vectors [27]. Knowledge of mosquito endemicity and mosquito vector density is very important as important parameters to assess the success of vector control programs [2].

In this study, no filariasis larvae were found in all mosquitoes caught by dissection and PCR methods, so the infection rates could not be determined. Thus, filariasis vectors in this area cannot be determined because the discovery of filariasis larvae in the mosquito's body is needed to confirm mosquitoes as vectors. In addition, the discovery of Ar. subalbatus, which is very dominant in Lubuk Pauh Village, can also be considered as a filariasis vector because in Papua Armigeres spp. have also been identified as filariasis vectors makers of human and animal-sourced disease control [23]. The existence of certain mosquito species, especially mosquitoes transmitting diseases in an area can be important information to be followed up. The results of this study can be used as supporting data for programs in conducting vector control activities. Continuous (longitudinal) observations of certain species as vectors need to be done routinely to provide more complete and useful information for policy programs.

\section{Conclusion}

In Lubuk Pauh Village as a nocturnal subperiodic $B$. malayi endemic area, four mosquito species were caught, and Ar. subalbatus was the dominant species, and it had the most frequent activity in each of the periods, both indoor and outdoor collection. Other mosquitoes collected were $C x$. quinquefasciatus, Cx. vishnui, and Ma. uniformis although in small numbers. B. malayi larvae were not found in all mosquito species caught; however, the discovery of $A r$. subalbatus, Cx. quinquefasciatus, and Ma. uniformis indicates that the area is at risk of transmission of lymphatic filariasis. Further studies need to be carried out with several mosquito samples to illustrate the effect of climate on the presence of mosquitoes in an area.

\section{Authors' Contributions}

BM designed the study, SRU and SH conducted the field survey, and EE collected mosquito samples. All authors drafted, revised, read, and approved the final manuscript.

\section{Acknowledgments}

The authors express our gratitude to the various parties who have assisted in the implementation of this research, including the Head of Lubuk Pauh Village, Volunteer Catchers of Mosquitoes and Technicians from the Department of Parasitology, Faculty of Medicine, Public Health, and Nursing Universitas Gadjah Mada: Mr. Purwono, Mrs. Kuswati, and Mrs. Rumbiwati for helping laboratory work. This study was financially supported by the Faculty of Medicine, Public Health, and Nursing Universitas Gadjah Mada, Indonesia (No. Project: UPPM/359/M/05/04/05.18).

\section{Competing Interests}

The authors declare that they have no competing interests.

\section{Publisher's Note}

Veterinary World remains neutral with regard to jurisdictional claims in published institutional affiliation.

\section{References}

1. World Health Organization. (2018) Lymphatic Filariasis. Available from: https://www.who.int/news-room/factsheets/detail/lymphatic-filariasis. Last accessed on 08-11-2018.

2. Ministry of Health (MOH) of Indonesia. (2015) Filariasis: Towards Filariasis Elimination 2020. Indonesian Ministry of Health's Data and Information Center. Jakarta.

3. Provincial Health Office of South Sumatera Indonesia. (2016) Annual Report.

4. WHO. Lymphatic filariasis: A handbook of practical entomology for national lymphatic filariasis elimination programs. WHO/HTM/NTD/PCT/2013.10. Italy: Department for International Development of the Government of the United Kingdom of Great Britain and Northern Ireland; 2013. Available at https://apps.who.int/iris/bitstream/ handle/10665/87989/9789241505642_eng.pdf;jsession$\mathrm{id}=2574 \mathrm{E} 90 \mathrm{EECCBC} 1 \mathrm{~F} 9 \mathrm{DDA} 86 \mathrm{E} 1 \mathrm{E} 2 \mathrm{~A} 9 \mathrm{FAC} 73$ ?sequence $=1$, Last accessed on 24-10-2019.

5. Ministry of Health (MOH) of Indonesia. (2014) Regulation of the Minister of Health of the Republic of Indonesia Number 94 of 2014 Concerning the Prevention of Filariasis. Jakarta.

6. Kanjanopas,K.,Choochote,W.,Jitpakdi,A., Suvannadabba,S., Loymak, S., Chungpivat, S. and Nithiuthai, S. (2001) Brugia malayi in a naturally infected cat from Narathiwat province, Southern Thailand. Southeast Asian J. Trop. Med. Public Health, 32(3): 585-587.

7. Sudjadi, F.A. (1996) Filariasis in Some Endemic Areas in East Kalimantan. Intraspecific Study B. Malayi Causes of Disease and Some Epidemiological Aspects. Dissertation. Universitas Gadjah Mada. Yogyakarta.

8. Mishra, K., Raj, D.K., Dash, A.P and Hazra, R.K. (2005) Combined detection of Brugia malayi and Wuchereria bancrofti using single PCR. Acta Trop., 93(3): 233-237.

9. Mårtensson, R. (2016) Species and Biological DiversityChoices of Diversity Indices and their Potential Consequences for Nature Conservation. Student Paper, Lund Universitet. Available from: http://www.lup.lub.lu.se/luur/ download? func $=$ downloadFile $\&$ recordOId $=8876148 \&$ fileOId $=8876149$, Last accessed on 22-10-2019.

10. Juhairiyah, J., Hidayat, S., Hairani, B., Fakhrizal, D. and Setyaningtyas, D.E. (2018) Diversity and behavior of mosquitoes on filariasis endemic area in Barito Kuala district, South Kalimantan. BALABA, 14(1): 31-42.

11. Manguin, S., Mouchet, J. and Carnevale, P. (2011) Main Topics in Entomology: Insects and Disease Vector, Green Trends in Insect Control. In: Lopez, O. and FernandezBalanos, J., editors. RSC Green Chemintry No. 11. Ch. 1. Royal Society of Chemistry. 1-52. Available from: https:// pubs.rsc.org/en/content/ebook/978-1-84973-149-2, Last accessed on 25-10-2019.

12. Rahman, G.M.S. (2017) Manholes as an important breeding site for Culex mosquitoes in Gazipur city corporation, Bangladesh. Bangladesh J. Zool., 45(2): 139-148.

13. Liu, H., Lu, H.J., Liu, Z.J., Jing, J., Ren, J.Q., Liu, Y.Y., Lu, F. and Jin, N.Y. (2013) Japanese encephalitis virus in mosquitoes and swine in Yunnan province, China 20092010. Vector Borne Zoonotic Dis., 13(1): 41-49.

14. Das, P., Bhattacharya, S., Palit, C.A., Das, S., Ghosh, K.K. and Hati, A.K. (1983) Diurnal man-biting activity of 
Armigeres subalbatus (Coquillet, 1898) in a village in West Bengal. Indian J. Med. Res., 78: 794-798.

15. Cheong, W.H., Mak, J.W., Naidu, S. and Mahadevan, S. (1981) Armigeres subalbatus incriminated as an important vector of the dog heartworm Dirofilaria immitis and the bird Cardiofilaria in urban Kuala Lumpur. Southeast Asian J. Trop. Med. Public Health, 12(4): 611-612.

16. Muslim, A., Fong, M.Y., Mahmud, R., Lau, Y.L. and Sivanandam, S. (2013) Armigeres subalbatus incriminated as a vector of zoonotic Brugia pahangi filariasis in suburban Kuala Lumpur, Peninsular Malaysia. Parasit. Vectors, 6(1): 219.

17. Shriram, A.N., Krishnamoorthy, K. and Vijayachari, P. (2015) Diurnally subperiodic filariasis among the Nicobarese of Nicobar district epidemiology, vector dynamics and prospects of elimination. Indian J. Med. Res., 141(5): 598-607.

18. Irish, S.R., Moore, S.J., Derua, Y.A., Bruce. J. and Cameron, M.M. (2013) Evaluation of gravid traps for the collection of Culex quinquefasciatus, a vector of lymphatic filariasis in Tanzania. Trans. R. Soc. Trop. Med. Hyg., 107(1): 15-22.

19. Safitri, A. (2011) Identification of Potential Vector and Vector of Filariasis Endemic Area in South Kalimantan in [Research Final Report]. Research Institute and Development of Animal Borne Diseases Control Tanah Bumbu.

20. Yahya, Y, Santoso, S., Salim, M. and Arisanti, M. (2014) PCR-based detection of Brugia malayi on experimentally infected Armigeres subalbatus and Culex quinquefasciatus. ASPIRATOR, 6(2): 35-42.
21. Mulyaningsih, B., Umniyati, S.R., Hadisusanto, S. and Edyansyah, E. (2019) Mansonia uniformis: A locally important vector of Brugia malayi nocturnally sub-periodic type in South Sumatera of Indonesia. Southeast Asian J. Trop. Med. Public Health, 50(4): 635-642.

22. Sitorus, H., Santoso, S., Budiyanto, A., Ambarita, L.P., Hapsari, N. and Taviv, Y. (2015) Species diversity of mosquito in endemic area of lymphatic filariasis in banyuasin and malaria Oku Selatan district. BALABA, 11(2): 97-104.

23. Ministry of Health (MOH) of Indonesia. (2002) Guidelines for Determining Endemic Areas of Filariasis, Jakarta.

24. Sapada, I.E., Anwar, C. and Priadi, D.P. (2015) Environmental and socio-economic factors associated with cases of clinical filariasis in Banyuasin District of South Sumatera, Indonesia. Int. J. Collab. Res. Intern. Med. Public Health, 7(6): 132-140.

25. Zen, S. (2015) Study of mosquito communities causing filariasis in Bojong village, East Lampung district. Bioedukasi, 6(2): 129-133.

26. Aure, W., Torno, M., Malijan, R.P., Cruz, E., Hernandez, L., Baquilod, M., Bangs, M. and Salazar, F.V. (2016) Investigation of mosquitoes with emphasis on Aedes (Finlaya) joicilius, putative vector of bancroftian filariasis on Panay Island, The Philippines. Southeast Asian J. Trop. Med. Public Health, 47(5): 912-926.

27. Haryuningtyas, D. and Subekti, D.T. (2008) Detection of Brugia malayi microfilaria/larvae in mosquito using polymerase chain reaction. Int. J. Agric. Vet. Sci., 13(3): 240-248. 